\title{
Effect of Environmental Factors on Incidence of Yellow Stem Borer (Scirpophaga incertulas Walker) in Rice (O. sativa L.) Ecosystem of Varanasi Region
}

\author{
Ingle Dipak Shyamrao* and M. Raghuraman \\ Department of Entomology and Agricultural Zoology, Institute of Agricultural Sciences, \\ Banaras Hindu University, Varanasi (U.P.), India \\ *Corresponding author
}

Keywords

Dead hearts,

Environmental factors, Rice, White ear head, Yellow stem borer

Article Info

Accepted:

17 May 2019

Available Online:

10 June 2019

\section{A B S T R A C T}

The present investigation was conducted on submergence rice variety Swarna sub-1 to study the effect of environmental factors on the incidence of yellow stem borer, Scirpophaga incertulas (Walker) during Kharif season of 2016 and 2017 at Agricultural Research Farm, Institute of Agricultural Sciences, Banaras Hindu University, Varanasi. The infestation of yellow stem borer was noticed in the field from $2^{\text {nd }}$ week of July to $4^{\text {th }}$ week of October during both Kharif season of 2016 and 2017. The maximum dead hearts (DH) and white ear head (WEH) were recorded in $40^{\text {th }}$ Standard meteorological week (SMW) $(8.48 \% \mathrm{DH})$ and $44^{\text {th }}$ Standard meteorological week (SMW) $(8.10 \% \mathrm{WEH})$ during both Kharif seasons of 2016 and 2017. These studies revealed that per cent dead heart was a significant positive correlation with maximum, minimum and average temperature, evening and average relative humidity while white ear head showed a significant positive correlation with maximum and minimum temperature and evening and average relative humidity. Other parameters showed a negative relationship with the dead heart and white ear head of yellow stem borer.

\section{Introduction}

Rice is one of the major food crops in the world, providing food for fifty per cent of the world population (Anonymous, 2004). About 90 per cent of rice is grown and consumed in Asian countries (Khush and Brar, 2002). Severe use of fertilizers particularly nitrogenous fertilizers, high yielding varieties, sequential cropping and arbitrary use of insecticides have resulted in the development of insect pests (Gupta et al., 2002). In India, approximately 100 insect species have been reported on rice and out of the 20 species causing 30 per cent yield loss from seedling to maturity (Atwal and Dhaliwal, 2005). Among them, yellow stem borer is distributed throughout India and regarded as most dominating and destructive pest species causing about 25-30 per cent loss in yield and it causes27.34 per cent losses annually (Pasulu et al., 2002 and Cattling et al., 1987). Larvae of yellow stem borer bore into the stem and feed inside. As results of central 
shoot withers and produces dead heart at vegetative stage and white ear heads at maturity stage. This can lead to the complete failure of the crop (Karthikeyan and Purushothaman, 2000). It is the most destructive insect pests of the rice crop and responsible for an annual yield loss of 10 to 15 per cent with local catastrophic outbreaks causing up to 60 per cent damage (Daryaei, 2005). The yellow stem borer Scirpophaga incertulas (Walker) solely causes 2-20 per cent damage and for increase in every per cent of white ears there was 1.3 per cent yield loss observed (Satpathi et al., 2012) and also caused 1 to 19 per cent yield loss in early planted rice crops and 38 to 80 per cent in late planted rice (Catinding and Heong, 2003). Yield loss is found positively correlated with the dead heart and white ear head infestations of vegetative and reproductive phase of the crop, respectively (Rahman et al., 2004).

Environmental factors play an important role in crop growth as well as development of pest and diseases. Environmental factors viz., temperature, moisture, light etc. have a direct influence on the development of insect pests. Wind and rainfall are important not only for survival but also for disposal of insect population (Saxena and Murty, 2014). Keeping these points in view, an experiment was conducted to assess the effect of environmental factors on the yellow stem borer population during Kharif 2016 and 2017.

\section{Materials and Methods}

Experimental site of Agriculture Research Farm of Institute of Agricultural Sciences, Banaras Hindu University, Varanasi, Uttar Pradesh, India lies between $24^{\circ} 56^{\prime} \mathrm{N}$ to $25^{\circ}$ $35^{\prime} \mathrm{N}$ Latitude and $82^{\circ} 14^{\prime} \mathrm{E}$ to $83^{\circ} 24^{\prime} \mathrm{E}$ Longitude and the elevation is $82 \mathrm{~m}$ above the mean sea level, almost in the centre of IndoGangetic belt. It possesses sub-tropical climate and annual rainfall ranges from 1.5 $\mathrm{mm}$ to $175.6 \mathrm{~mm}$ and $1.0 \mathrm{~mm}$ to $139.8 \mathrm{~mm}$ received during Kharif 2016-17 and Kharif 2017-18. A bulk plot of $100 \mathrm{~m}^{2}$ was raised adjacent to the main experiment plot so as to study the population build up of the pest under the study. The pest population was recorded in this unprotected plot at the weekly interval from the occurrence or initiation of pest infestation and was continued up to crop maturity. The incidence of the pest was recorded at 10 randomly selected hills. Weather data were recorded simultaneously from the meteorological observatory available at Department of Agronomy, Agricultural Research Farm, Institute of Agricultural Sciences, Banaras Hindu University, Varanasi. Meteorological observations viz., temperature (Maximum and Minimum), relative humidity (Maximum and Minimum), rainfall and these observations were correlated with the occurrence of the pest population. A correlation coefficient method was adopted to work out the relationship between the occurrence of the pest and weather parameters correlation method was adopted. The per cent incidence (dead hearts/ white ears) was calculated as follows:

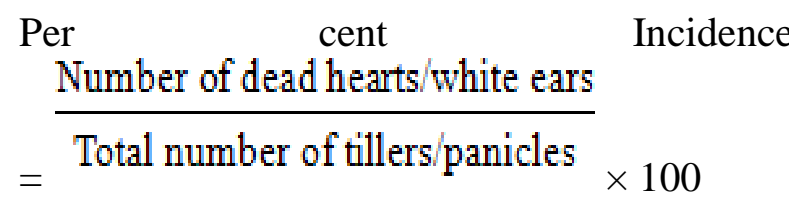

\section{Results and Discussion}

\section{Kharif 2016-17}

The data pertaining to mean per cent incidence of $S$. incertulas (Walker) has been illustrated in figure 1 . The data recorded on the seasonal incidence of yellow stem borer, $S$. incertulas was taken in two phases first from tillering to panicle initiation as per cent dead hearts during the vegetative stage and the second phase from panicle initiation till 
harvest as per cent white ears during the reproductive stage. The damage symptoms were observed for the first time during $30^{\text {th }}$ standard meteorological week i.e., three weeks after transplanting. It was evident from the figure that the dead hearts $(\mathrm{DH})$ and white ear heads incidence of yellow stem borer ranged from 0.51 to 8.48 per cent and 7.21 to 8.10 per cent during the course of study.

The maximum dead hearts $(8.48 \%)$ incidence noticed in the $40^{\text {th }}$ standard meteorological week (SMW) followed by 7.41 and 6.72 per cent noticed in the $39^{\text {th }}$ and $38^{\text {th }}$ standard meteorological week, respectively. Whereas, minimum dead hearts $(0.51 \%)$ incidence was recorded in the $30^{\text {th }}$ standard meteorological week (SMW).

The maximum white ear head $(8.10 \%)$ incidence was noticed in the $44^{\text {th }}$ standard meteorological week (SMW) followed by 7.72 and 7.52 per cent during $43^{\text {rd }}$ and $42^{\text {nd }}$ standard meteorological week (SMW) whereas, minimum white ear head $(7.21 \%)$ incidence was recorded in the $41^{\text {st }}$ standard meteorological week (SMW). It clearly indicates that the dead hearts and white ear head incidence gradually increased from $30^{\text {th }}$ to $40^{\text {th }}$ and $41^{\text {st }}$ to $44^{\text {th }}$ standard meteorological week (SMW), thereafter declined trend was recorded during the course of the investigation. A correlation was worked out to find out the relationship between the per cent dead hearts and white ear head and weather parameters.

The results showed a significant positive correlation with minimum temperature $(r=$ $\left.0.492^{*}\right)$, evening $\mathrm{RH}\left(\mathrm{r}=0.545^{*}\right)$ and average relative humidity $\left(\mathrm{r}=0.494^{*}\right)$, positive nonsignificant correlation with other parameters (Table 1). However, the relationship between the per cent white ear heads and major weather parameters showed that there is a highly significant positive correlation with morning $(\mathrm{r}=0.659 * *)$, evening $\left(\mathrm{r}=0.668^{* *}\right)$ and average relative humidity $(\mathrm{r}=0.675 * *)$ and significant positive correlation with maximum temperature $\left(\mathrm{r}=0.544^{*}\right)$ (Table 1$)$.

\section{Kharif 2017-18}

The incidence was observed for the first time during the $29^{\text {th }}$ standard meteorological week. It was evident from the figure 2 that the dead hearts (DH) and white ear head incidence of yellow stem borer ranged from 0.28 to 8.34 per cent and 6.55 to 8.88 per cent during the course of study.

The maximum dead hearts $(8.34 \%)$ was noticed in the $39^{\text {th }}$ standard meteorological week (SMW) followed by 7.18 and 6.20 per cent noticed in the $38^{\text {th }}$ and $37^{\text {th }}$ standard meteorological week, respectively. Whereas, minimum dead hearts $(0.28 \%)$ was recorded in the $29^{\text {th }}$ standard meteorological week (SMW). The maximum white ear head (8.88 $\%$ was noticed in the $44^{\text {th }}$ standard meteorological week (SMW) followed by 8.64 and 8.10 per cent during $43^{\text {rd }}$ and $42^{\text {nd }}$ standard meteorological week (SMW).

Whereas, minimum white ear head $(6.55 \%)$ was recorded in $10^{\text {th }}$ standard meteorological week (SMW). It clearly indicates that the dead hearts and white ear head incidence gradually increased from $29^{\text {th }}$ to $40^{\text {th }}$ and $41^{\text {st }}$ to $44^{\text {th }}$ standard meteorological week (SMW), thereafter declined trend was recorded during the course of an investigation.

A correlation was worked out to find out the relationship between the per cent dead hearts and white ear head and weather parameters. The results showed a significant positive correlation with maximum, minimum and average temperature with $\mathrm{r}=0.525,0.511$ and 0.577 (Table 2). Non-significant negative correlation with evening $(\mathrm{r}=-0.469)$ and average $\mathrm{RH}(\mathrm{r}=-0.490)$, respectively. 
Fig.1 Influence of abiotic factors on seasonal incidence of yellow stem borer of rice during Kharif- 2016

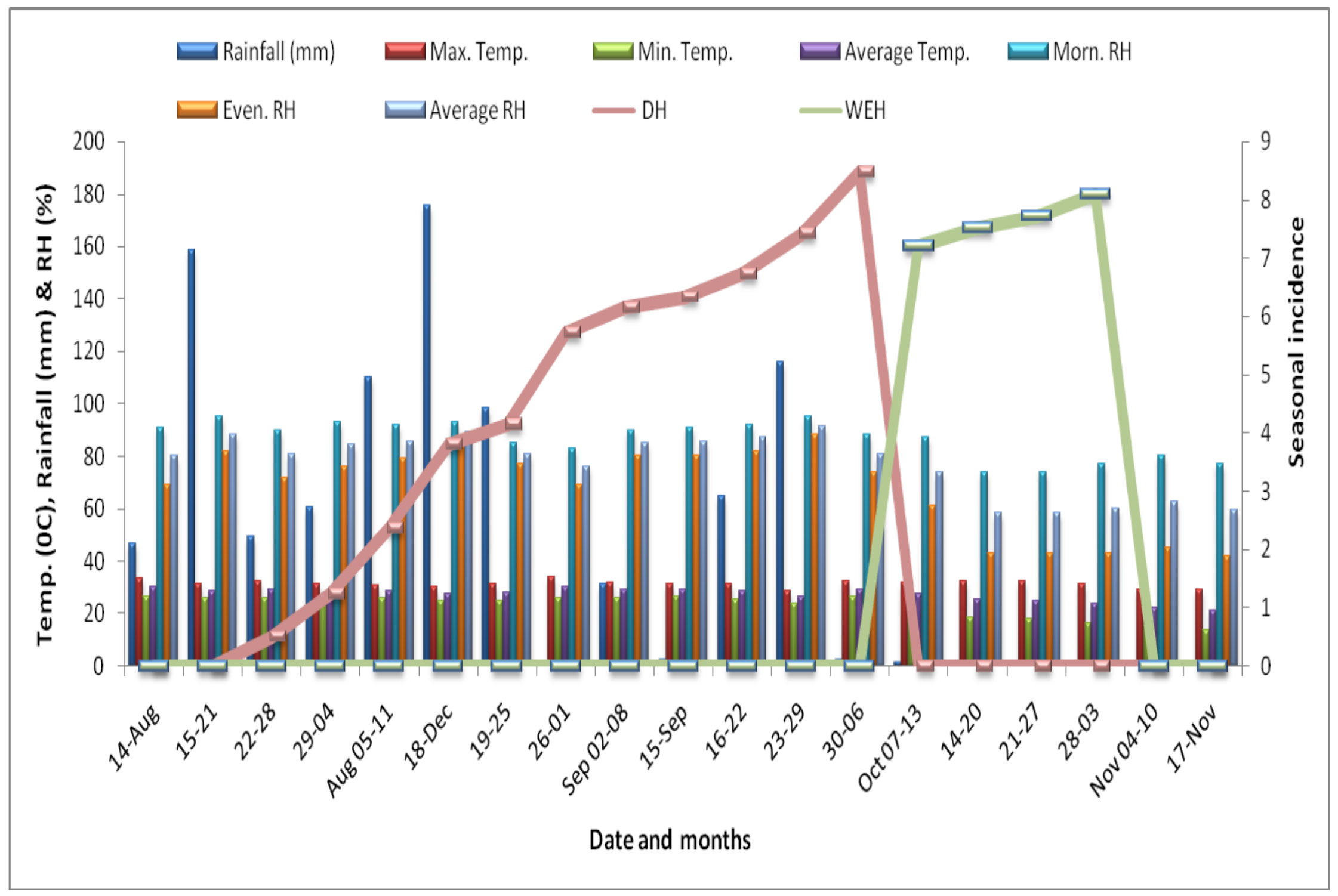


Fig.2 Influence of abiotic factors on seasonal incidence of yellow stem borer of rice during Kharif- 2017

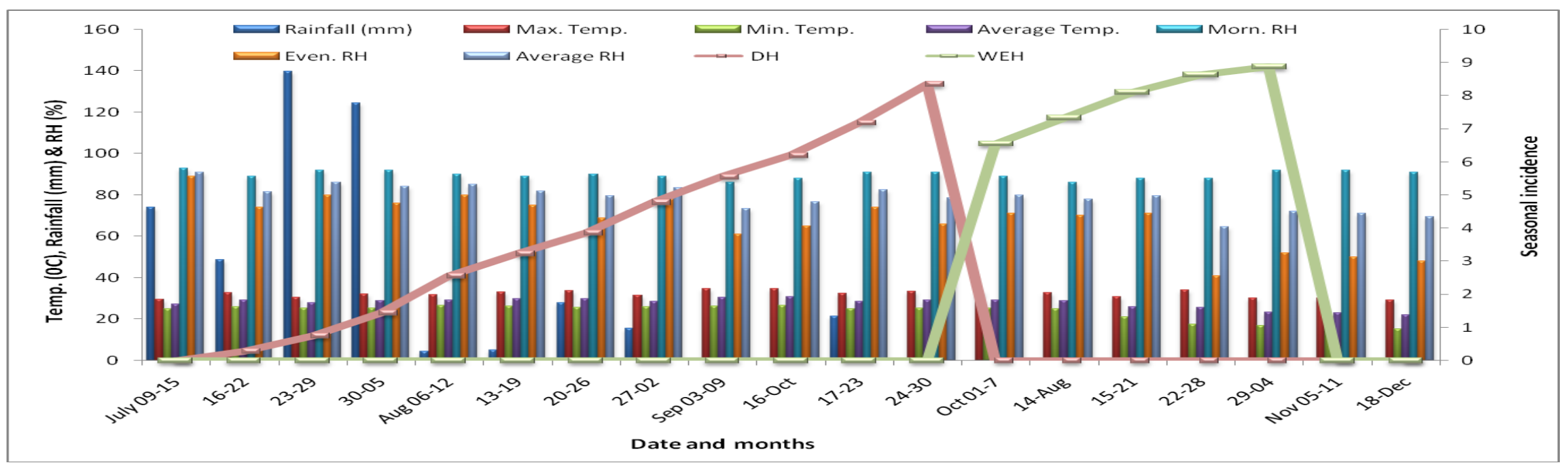

Table.1 Correlation coefficient of insect pest population on rice with prevailing weather parameters during Kharif- 2016

\begin{tabular}{|c|c|c|c|c|c|c|c|c|}
\hline \multirow{2}{*}{\multicolumn{2}{|c|}{ Insect pests }} & \multicolumn{7}{|c|}{ Weather parameters } \\
\hline & & \multirow{2}{*}{$\begin{array}{l}\text { Rainfall } \\
\text { (mm) }\end{array}$} & \multicolumn{3}{|c|}{ Temperature } & \multicolumn{3}{|c|}{ Relative Humidity } \\
\hline & & & Maximum & Minimum & Average & Morning & Evening & Average \\
\hline \multirow{2}{*}{$\begin{array}{c}\text { Yellow stem } \\
\text { borer }\end{array}$} & $\% \mathrm{DH}$ & -0.045 & 0.034 & $0.492 *$ & 0.429 & 0.353 & $0.545^{*}$ & $0.494 *$ \\
\hline & $\% \mathrm{WEH}$ & -0.440 & $0.544 *$ & $-0.509 *$ & -0.367 & $0.659 * *$ & $0.668 * *$ & $0.675 * *$ \\
\hline
\end{tabular}

Table.2 Correlation coefficient of yellow stem borer population on rice with prevailing weather parameters during Kharif- 2017

\begin{tabular}{|c|c|c|c|c|c|c|c|c|}
\hline \multirow{3}{*}{\multicolumn{2}{|c|}{ Insect pests }} & \multicolumn{7}{|c|}{ Weather parameters } \\
\hline & & \multirow{2}{*}{$\begin{array}{c}\text { Rainfall } \\
(\mathbf{m m})\end{array}$} & \multicolumn{3}{|c|}{ Temperature } & \multicolumn{3}{|c|}{ Relative Humidity } \\
\hline & & & Maximum & Minimum & Average & Morning & Evening & Average \\
\hline \multirow{2}{*}{$\begin{array}{c}\text { Yellow stem } \\
\text { borer }\end{array}$} & $\% \mathrm{DH}$ & -0.187 & $0.525^{*}$ & $0.511^{*}$ & $0.577 * *$ & -0.131 & 0.158 & 0.131 \\
\hline & $\% \mathrm{WEH}$ & -0.378 & -0.072 & $0.528 *$ & -0.436 & -0.238 & $-0.469 *$ & $-0.490 *$ \\
\hline
\end{tabular}


The present finding is in close conformity with the report of Bora et al., (1995) who reported that the pest incidence was higher in the vegetative stage with a peak level of damage (9.0-12.5\% dead hearts) recorded 6-7 weeks after transplanting, whereas in the reproductive stage damage was low (0.4-0.6\% WEH) in the ahu crop.

Maximum pest incidence $(8.72 \% \mathrm{DH})$ was recorded during the first week of October 1991 in the Sali crop. White ear head damage was greater in the Sali crop than the ahu during both years. Further Kumar and Sudhakar (2001) who reported that the peak activity of yellow stem borer was observed in the second fortnight of October during Kharif 1998 and in the second fortnight of March during rabi 1998/99. Justin and Preetha (2013) reported that the weather parameters showed a significant positive correlation with relative humidity but negative correlation with minimum temperature and rainfall respectively.

In conclusion, the infestation of yellow stem borer was noticed in the field from $2^{\text {nd }}$ week of July to $4^{\text {th }}$ week of October during both the year of study. The maximum dead hearts (DH) and white ear head (WEH) were recorded in the month of September and October during Kharif season of 2016 and 2017.

Population fluctuation was correlated with environmental factors which showed that significant positive correlation with maximum, minimum and average temperature, evening and average relative humidity while white ear head showed a highly significant positive correlation with morning, evening and average relative humidity. Other parameters showed a negative relationship with dead heart and white ear head of yellow stem borer.

\section{Acknowledgment}

The authors are grateful to the Head, Department of Entomology and agricultural Zoology, Institute of Agricultural Sciences, Banaras Hindu University, Varanasi for providing the necessary help required during the experiment.

\section{References}

Anonymous. 2004. Food and Agricultural Organization of the United Nations. The state of food security in the world, pp 30.

Atwal, A.S. and Dhaliwal, G.S. 2005. Agricultural Pests of South Asia and their management. Kalyani Publishers, New Delhi Pp. 181-182.

Bora, D.K., Saharia, D. and Hussain, S. 1995. Seasonal incidence of stem borers in ahu and Sali rice. Journal of the Agricultural Science Society of North East India 8(1): 10-13.

Catinding, J.L.A. and Heong, H.L. 2003. Rice Doctor@2003, IRRI, Phillipines pp. 110.

Catling, H., Islam, D.Z. and Pattrasudhi. 1987. Assessing yield losses in deep water rice due to yellow stem borer, $S$. incertulas in Bangladesh and Thailand. Crop Protection Journal 6: 20- 27.

Daryaei, M.G. 2005. Assessment of yield loss in rice due to yellow stem borer, Scirpophaga incertulas using simulation models. Caspian J. Environ. Sci. 3: 59-62.

Gupta, S.P., Pandey, U.S., Pandey, V. and Mishra, C.H. 2002. Screening of rice cultivars under wet condition against major insect pests of rice. Shashpa 9(2): 189-190.

Justin, C.G.L. and Preetha, G. 2013. Seasonal incidence of rice yellow stem borer, Scirpophaga incertulas (Walker) in Tamil Nadu. Indian Journal of 
Entomology 75(2):109-112.

Karthikeyan, K. and Purushothaman, S.M. 2000. Efficacy of carbosulfan against rice yellow stem borer, $S$. incertulas Walker (Pyralidae: Lepidoptera). Indian Journal of Plant Protection 28: 212-214.

Khush, G.S. and Brar, D.S. 2002. Biotechnology for rice breeding: Progress and Potential. In Proceeding of the $20^{\text {th }}$ season of International Rice Commission $\quad\left(23^{\text {rd }}-26^{\text {th }}\right.$ July, Bankok, Thailand).

Pasulu, I.C., Krishnaiah, N.V., Kotti, G. and Varma, N.R.G. 2002. IPM in rice mitr., pp. 45-55.

Rahman, M.T., Khalequzzaman, M. and Khan, M.A.R. 2004. Assessment of infestation and yield loss by stem borers on variety of rice. Journal of Asia-
Pacific Entomology 7(1): 89-95.

Satpathi, C.R., Chakraborty, K., Shikari, D. and Acharjee, I.P. 2012. Consequences of feeding by yellow stem borer (Scirpophaga incertulas Walk.) on Rice cultivar Swarna Masuri (MTU 7029). World Applied Sciences Journal 17(4): 532-539.

Saxena, S. and Murty, R.F. 2014. Weather based model development for outbreak of mustard aphid (L. erysimi) using artificial neural network. The Ecoscan 8: 47-52.

Singh, M and Singh, R.P. 2010. Efficacy of herbicides under different methods of direct-seeded rice establishments. Indian Journal of Agricultural Sciences 80(9): 815-19.

\section{How to cite this article:}

Ingle Dipak Shyamrao and Raghuraman, M. 2019. Effect of Environmental Factors on Incidence of Yellow Stem Borer (Scirpophaga incertulas Walker) in Rice (O. sativa L.) Ecosystem of Varanasi Region. Int.J.Curr.Microbiol.App.Sci. 8(06): 2416-2422. doi: https://doi.org/10.20546/ijcmas.2019.806.288 